\title{
Hotspots Inquiry of Private Capital into Infrastructure
}

\author{
Zhang Ningchuan ${ }^{1,}$, Zhao Xinyu ${ }^{2, b}$ \\ ${ }^{1}$ Economics and Management School of Wuhan University, China \\ ${ }^{2}$ Economics and Management School of Wuhan University, China \\ a119063279@qq.com, b119063279@qq.com
} Keywords: Infrastructure; Non-state capital; Government investment; Economic growth;
Investment system

\begin{abstract}
With the slowing growth of China's economic, infrastructure construction, due to its slower return on investment, is more difficult to get financial support. But the further development of China's economy must rely on sound infrastructure. We need to introduce a new investment mechanism based on construction of facilities to inject new vitality. On the other hand, non-state capital in the financial sector speculation is intensified and standardization of the hot money is imperative. In this case, leading private capital into infrastructure construction has become a new topic. This article is to explore non-state capital brought into infrastructure, focusing on the relationship between non-state capital and government investment, economics advantages of the non-state capital being taken into infrastructure field and the policy options in specific operation.
\end{abstract}

\section{Concepts of infrastructure and private capital}

\section{Concept of infrastructure \\ Definition of infrastructure}

Economic Encyclopedia defines infrastructure as: "Infrastructure refers to the economic projects that have direct or indirect influence in the improvement of output or production efficiency, mainly including transportation systems, power generation facilities, communication facilities, financial facilities, educational and sanitary facilities, as well as a well-organized government and the political system.”

\section{Characteristics of the infrastructure}

Generally, the infrastructure is characterized in having the following aspects: (1) Social. The vast majority of infrastructure companies' products or services provided by the producers are for consumers of the whole of society. (2) Non-exclusive. That is, the individual cannot have an infrastructure or services of their exclusive, and exclude others from the use of the facility. (3) Scale. Infrastructure belongs to the fixed asset investment projects; the investment is of large-scale and long service life. And market cycle is stable; the revenue can be assured (Figure 1)

Infrastructure investment has become the main force of China's economic growth

China's economy has entered the stage of the slowdown in growth. Due to the economic slowdown of the world's major trading nations, export in the short term is difficult to have significant increase. Consumption is mainly affected by the buyer's market and the constraints of their purchasing power. As a major component of investment in fixed assets, infrastructure has a strong stimulating effect on economic growth. According to the sheet, final demand of each additional unit of investment in the infrastructure sector is induced by various departments of production amounted to 0.8758 , second only to the buildings sector. Thus, the increase in investment in the infrastructure sector will receive more obvious output than the other departments. 


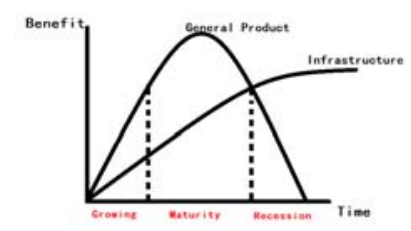

Figure 1 Comparison of life cycle between Infrastructure and general product

Table 1 Comparison among national economic sectors in promoting economic growth

\begin{tabular}{ccccccc}
\hline \hline Sector & Agriculture & $\begin{array}{c}\text { Manufacturin } \\
\text { g industry }\end{array}$ & $\begin{array}{c}\text { Construction } \\
\text { industry }\end{array}$ & $\begin{array}{c}\text { Service } \\
\text { industry }\end{array}$ & Commerce & infrastructure \\
\hline Investment induced coefficient & 0.4224 & 0.6752 & 2.3298 & 0.0249 & 0.6286 & 0.8758 \\
\hline \hline
\end{tabular}

Source: Wang Guoding, Lv Litao: "On infrastructure's status and the relationship with sectors of other departments ", "economic issues", the $4^{\text {th }}$ issue in 2001, P4 to 7.

\section{Concept of private capital}

The definition of private capital can be divided into three. The first is a view of narrow school of thought. From the angle with respect to public ownership, private investment is defined as non-public ownership investment that does not include four major sectors of the economy: The joint-stock enterprises, association economy, the collective economy, foreign capital,but specifically refers to the individual economy and private economy.

The second is the neutral point of view. From the point of view with respect to the investment of government capital investment and state-owned enterprises, it is defined as private enterprises investment other than government capital and capital of state-owned enterprises.

The third is a view of wide school of thought. All capital investments except government capital belong to private capital investment, including state-owned enterprises, individual enterprises, private enterprises, foreign-funded enterprises and other non-state-owned economic investment. The common feature of this part of the capital is that the capital management objective is to maximize profits.

\section{The choice of the path of private capital's entry into infrastructure}

\section{Investment Fund}

The establishment of investment funds can effectively collect social idle funds, directly gets involved in the key infrastructure construction projects. At least for now, it is the best way to address the shortage of infrastructure funding. Through the formation of the fund management companies, set up a fund to specific or non-specific investors, scatter funds for investment in various infrastructure projects, achieve capital appreciation through equity transfer by the completion of the project, the benefits and risks of investment will be shared by investors. The mode of operation is as follows:

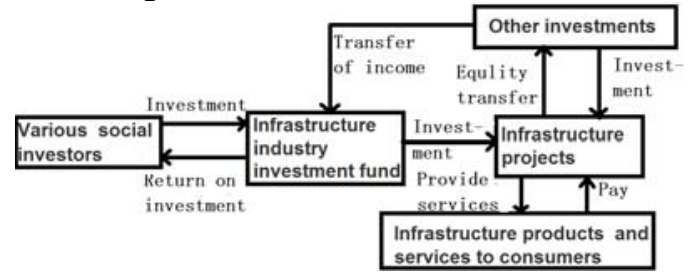

Figure 2 Investment funds operating mode

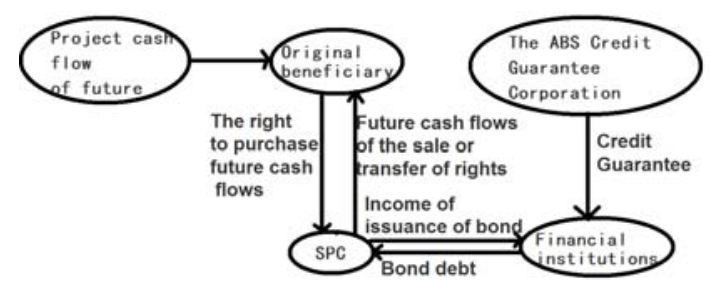

Figure 3 ABS mode of operation

\section{BOT way}

BOT is a relatively new type of contract direct investment; BOT is abbreviation of Build-Operate-Transfer. It applies to state and local governments in attracting investment enterprises into the financing and construction of large-scale infrastructure projects, operation and maintenance in infrastructure sector through the franchise agreement. For the government, taking BOT in private capital ensures government's control of infrastructure, passes on the investment risk, has a very important significance. In essence, the BOT is a special mode of operation in which the government and contractor co-operate in infrastructure projects. Civil BOT is mainly applied to 
power generation facilities, bridges, tunnels, urban water supply and so on.

\section{ABS mode of financing}

ABS (Asset-Backed-Securitization) is a new infrastructure financing that recently emerged, whose basic form is to issue bonds for financing of lower costs in the domestic and international capital market with project assets as foundation and the future benefits of the project assets as guarantee. Asset securitization financing methods aimed at enhancing the credit rating of the originally securities with lower credit ratings to enter the international high-grade securities market through the means of financing the unique mechanism to by using high-grade securities market high mobility, low interest rates and high security, a significant reduction in the cost of raising funds for issue of securities will be seen. The brief icon of ABS operation process is as following:Through the formation of SPV (Special Purpose Vehicle), take over the project, financing, such as debt servicing work done by the SPV, without governmental credit guarantees for the repayment of the bonds.

\section{The obstacles of the entry of private capital}

\section{Concepts and administrative system disorders}

With the initial setting up of China's socialist market economy, people have a relatively clear understanding of the positioning of government and the market in the field of general competitive fields, but still lack of correct understanding in certain externalities and natural monopoly infrastructure industry positioning.

\section{Market access and obstacles of policy environment}

Although the policies encourage and allow private capital to enter a wide range of infrastructure, but in some good market with prospects and long-term stable income infrastructure sectors, there still exists a variety of barriers to entry, including local protectionism ownership discrimination, lack of legal protection.

\section{Other}

In addition to the two points above, the commercial bank and capital market financing difficulties, rights protection barriers, the lack of exit assistance mechanisms, flawed governance structure of state-owned enterprises have increased the degree of difficulty for private capital to go to the field of infrastructure.

\section{Conclusions}

The recovery of the world economy creates a favorable external environment for China's economic growth. Meanwhile, the 18th Congress of CPC put forward to continue to deepen the reform of the economic system, and the core issue is to properly handle the relationship between the government and the market. Unswervingly encourage, support and guide the development of non-public ownership economy, we can do as Eighteen Report said, "to win this tough battle of comprehensive deepening of economic reform and accelerate the transformation of economic development, to push our economic development vitality and competitiveness to a new level.”

Through this analysis, we can find that it has quite vast prospects and a huge advantage for private capital to enter infrastructure. Admittedly, this is an entirely new experience in the field of China's economy; it's in continual innovation of the reform of the economic system that makes the China's economy continue to shine with new vitality. The costly infrastructure construction is not enough to rely on government investment, in the context of the market economy, the introduction of private capital in infrastructure is the trend. At the same time, this finds a new way out for innovative private capital beyond speculation into the financial industry, which is conducive to the sound development of private capital. To break the stereotypes and innovate investment system is the era trend and will benefit the nation and the people!

\section{References}

[1] Holzscheiter, Anna. "Discourse as capability: non-state actors' capital in global governance." Millennium-Journal of International Studies 33.3 (2005): 723-746. 
[2] Newell, Peter. Climate for change: Non-state actors and the global politics of the greenhouse. Cambridge University Press, 2006.

[3] Michaels, Ralf. "Re-State-ment of Non-State Law: The State, Choice of Law, and the Challenge from Global Legal Pluralism, The." Wayne L. Rev. 51 (2005): 1209.

[4] Langhorne, Richard. "The diplomacy of non-state actors." Diplomacy and Statecraft 16.2 (2005): 331-339.

[5] Juwei, Zhang, and Xue Xinxin. "State and Non-state Sector Wage Differentials and Human Capital Contribution [J]." Economic Research Journal 4 (2008): 15-25.

[6] Li, David Daokui, Junxin Feng, and Hongping Jiang. "Institutional entrepreneurs." The American economic review 96.2 (2006): 358-362. 